\title{
Chemical composition of cultivated seaweed Ulva clathrata (Roth) C. Agardh
}

\author{
Alberto Peña-Rodríguez a , Thomas P. Mawhinney ${ }^{\mathrm{b}}$, Denis Ricque-Marie ${ }^{\mathrm{a}}$, L. Elizabeth Cruz-Suárez ${ }^{\mathrm{a}, *}$ \\ a Programa Maricultura, Universidad Autónoma de Nuevo León, Cd. Universitaria F-67, San Nicolás de los Garza, Nuevo León 66450, Mexico \\ ${ }^{\mathrm{b}}$ AESCL Analytical Services, University of Missouri, Columbia, MO 65211, USA
}

\section{A R T I C L E I N F O}

\section{Article history:}

Received 15 December 2010

Received in revised form 17 March 2011

Accepted 28 April 2011

Available online 7 May 2011

\section{Keywords:}

Chlorophyta

Ulva clathrata

Cultivated

Seaweed

Crude protein

Ash

Dietary fibre

Monosaccharides

Amino acids

Lipids

Fatty acids

PUFAs

Carotenoids

Minerals

\begin{abstract}
A B S T R A C T
Samples of cultivated Ulva clathrata were collected from a medium scale system (MSS, $1.5 \times 1.5 \mathrm{~m}$ tank), or from a large scale system (LSS, 0.8 ha earthen pond). MSS samples were dried directly while the LSS sample was washed in freshwater and pressed before drying. Crude protein content ranged 20-26\%, essential amino acids accounting for $32-36 \%$ of crude protein. The main analysed monosaccharides were rhamnose (36-40\%), uronic acids (27-29\%), xylose (10-13\%) and glucose (10-16\%). Some notable variations between MSS and LSS samples were observed for total dietary fibre (26\% vs $41 \%$ ), saturated fatty acids (31\% vs 51\%), PUFAS (33\% vs 13\%), carotenoids (358 vs $169 \mathrm{mg} \mathrm{kg}^{-1} \mathrm{dw}$ ) and for Ca (9 vs $19 \mathrm{~g} \mathrm{~kg}^{-1}$ ), $\mathrm{Fe}\left(0.6 \mathrm{vs} 4.2 \mathrm{~g} \mathrm{~kg}^{-1}\right), \mathrm{Cu}\left(44 \mathrm{vs} 14 \mathrm{mg} \mathrm{kg}^{-1}\right), \mathrm{Zn}\left(93 \mathrm{vs} 17 \mathrm{mg} \mathrm{kg}^{-1}\right)$ and As $\left(2 \mathrm{vs} 9 \mathrm{mg} \mathrm{kg}^{-1}\right)$. The chemical composition of $U$. clathrata indicates that it has a good potential for its use in human and animal food.
\end{abstract}

(c) 2011 Elsevier Ltd. All rights reserved.

\section{Introduction}

Seaweeds have been used for many different purposes, mainly for human consumption (Besada, Andrade, Schultze, \& González, 2009) but also as a source of hydrocolloids, for animal nutrition, waste water treatment, paper industry, cosmetics, fertilizers and medical research (Cruz-Suárez et al., 2010; Lahaye \& Jegou, 1993; McHugh, 2003). In general, seaweed natural stocks are insufficient to supply the increasing worldwide demand; as a consequence seaweeds culturing has been developed and provides now more than $90 \%$ of the seaweed market's demand (McHugh, 2003).

Green algae belonging to the genera Ulva, formerly Enteromorpha (Hayden et al., 2003), are common seaweeds distributed worldwide. They have an interesting chemical composition that makes their commercial exploitation attractive to produce functional or health promoting food. Ulvales are already being used in Asia as a food condiment and as a nutritional supplement in China, Japan, USA, France, and Chile. These algae are is harvested to prepare "aonori", which is included in a great variety of

\footnotetext{
* Corresponding author. Tel./fax: +52 (81) 83526380.

E-mail address: lucia.cruzsr@uanl.edu.mx (L.E. Cruz-Suárez).
}

dishes, including raw salads, soups, cookies, meals, and condiments (Aguilera-Morales, Casas-Valdez, Carrillo-Domínguez, González-Acosta, \& Perez-Gil, 2005). Interest in Ulvales as a novelty food is expanding in western countries. Although the chemical composition of Ulvales from some regions of the world has been documented, research has been focused especially on Ulva lactuca and Ulva pertusa and, to a lesser extent, on other species such as Ulva fasciata, Ulva rigida, Enteromorpha sp., Enteromorpha flexuosa, Enteromorpha intestinalis and Enteromorpha compressa. Few studies have been done on cultivated specimens; however, there are a number of studies that describe natural stocks collected from coastal or lagoon waters, where seaweed chemical composition varies depending on the geographical distribution and the season, the principal environmental factors being water temperature, salinity, light, and nutrients and minerals availability (Marinho-Soriano, Fonseca, Carneiro, \& Moreira, 2006).

There is no complete study on the chemical composition of $U$. clathrata that we know of; Cruz-Suárez, Tapia-Salazar, Nieto-Lopez, Guajardo-Barbosa, and Ricque-Marie (2009) and Cruz-Suárez et al. (2010) previously reported proximal and amino acid composition. The aim of the present study was to provide information on the proximal composition, dietary fibre, sugars, amino acids, fatty acids, carotenoids, and some minerals contents, of cultured green 
seaweed $U$. clathrata produced in México under medium and large scale culture systems (Moll, 2004). This information will be essential in the development of food commercial products based on cultivated $U$. clathrata.

\section{Materials and methods}

\subsection{Algal samples}

Four samples of cultivated $U$. clathrata were collected and analysed. Three samples were obtained from different production batches of a medium scale system (MSS) installed in a fiberglass tank, using filtered and ultra-violet irradiated oceanic water and a controlled fertilization schedule, and one sample from a large scale system (LSS) installed in a shrimp earthen pond, using coastal marine water with restricted and less controlled nitrogen fertilization compared to MSS.

All samples were cultivated in Sinaloa, México (2009), under a patented technology developed for high yield and low cost production, from a clonal laboratory stock of an $U$. clathrata known strain (Moll, 2004). Because planting stock was produced from a vegetative clone, all variations in composition we report are due to conditions of culture and post-harvest process, not genetic differences. Production was initiated from a diploid vegetative clone (sporophyte plant), which can reproduce by spores and produce a gametophytic generation; however the rate of spore production was so low that the material produced can be reasonably described as diploid, with only traces of haploid cells.

Light was natural daylight for both medium and large scale systems, with an average intensity of $800 \mu \mathrm{mol}$ photons $\mathrm{m}^{-2} \mathrm{sec}^{-1}$. MSS samples were obtained in a $1.5 \times 1.5 \mathrm{~m}$ container during three monthly periods (18 December-19 January, 12 February-11 March, 18 March-19 April), with temperatures at 6:00 and 12:00 in ranges of $6-19$ and $10-25^{\circ} \mathrm{C}, 9-20$ and $20-26^{\circ} \mathrm{C}, 12-18$ and $22-26^{\circ} \mathrm{C}$ for the respective periods; algal biomass density raised from $100 \mathrm{~g} \mathrm{~m}^{-2}$ to an average $3.5 \mathrm{~kg}$ fresh weight $\mathrm{m}^{-2}$. LSS sample was taken from the pooled production of two shrimp culture ponds (7800 and $8400 \mathrm{~m}^{2}$ ) after a two month growing period (01 Mar-06 May), with temperatures at 8:00 and 16:00 in ranges of 18-27 and $21-32{ }^{\circ} \mathrm{C}$; initial algal biomass density was $11-12 \mathrm{~g} \mathrm{~m}^{-2}$ and reached $2 \mathrm{~kg}$ fresh weight $\mathrm{m}^{-2}$.

The MSS Ulva samples, freshly collected, were directly dried at $60{ }^{\circ} \mathrm{C}$ to achieve $10 \%$ moisture; the LSS Ulva fresh biomass was washed in freshwater to remove sediment, epifauna and epiphytes, it was then pressed and dried at $50{ }^{\circ} \mathrm{C}$ in an industrial hot air dryer, and ground in the same industrial plant before the sample was collected. The dried samples were ground at laboratory (Cyclotec by Tecator) to pass through a $500 \mu \mathrm{m}$ sieve and stored in plastic bags at $4{ }^{\circ} \mathrm{C}$ temperature.

\subsection{Chemical analyses}

The chemical analyses of the Ulva samples were carried out at the AESCL Analytical Services, University of Missouri with the following methods: total nitrogen or crude protein, by Kjeldahl, using 6.25 as a conversion factor to calculate protein content (AOAC, Official Method 984.13 (A-D), 2006); crude fat with acid hydrolysis (AOAC, Official Method 954.02, 2006); ash determination (AOAC, Official Method 942.05, 2006); moisture by vacuum oven (AOAC, 2006); total dietary fibre (TDF), soluble dietary fibre (SDF) and insoluble dietary fibre (IDF) (AOAC, Official Method 985.29 and Official Method 991.43, 2006) (SDF was calculated by difference as TDF-IDF); complete amino acid profile (AOAC, Official Method 982.30 E (a-c), chp. 45.3.05, 2006); fatty acids profile - saturated, mono- and polyunsaturated, following AOAC (2006) procedures methods; total carotenoids (AOAC Official Method 938.04); xanthophylls (AOAC Official Method 970.64); metals and other elements analysis were made through atomic absorption spectrophotometry and/or by inductive coupled plasma-optical emission spectroscopy (ICP-OES) following the procedures described by AOAC (2006).

Sample aliquots were analysed for their carbohydrate composition as their alditol acetates via gas-liquid chromatography (GLC) and by gas-liquid chromatography-mass spectrometry (GLC-MS) based on the procedure by Oxley, Currie, and Bacic (2004). Briefly, dried sample aliquots were hydrolyzed with $500 \mu \mathrm{l}$ of $2.5 \mathrm{M}$ trifluoroacetic acid (TFA) in Teflon-capped tubes under an argon atmosphere for $4 \mathrm{~h}$ at $105^{\circ} \mathrm{C}$. After cooling, TFA was removed in vacuo and then 3-O-methyl-glucitol was added as the internal standard. Reacetylation of amino sugars was achieved by adding $1.0 \mathrm{ml}$ of dry methanol, chilled to $0^{\circ} \mathrm{C}$, to which was added $25 \mu$ l of acetic anhydride with rapid stirring. Following solvent removal in vacuo, carbohydrates were then reduced with sodium borodeuteride in $2 \mathrm{M} \mathrm{NH}_{4} \mathrm{OH}$ for $2.5 \mathrm{~h}$ at room temperature. Reactions were carefully acidified with $50 \mu \mathrm{l}$ acetic acid and dried. Boric acid was removed with the addition of methanol which was then evaporated under a stream of dry nitrogen. The resulting sugar alcohols were then acetylated with the addition of $1.0 \mathrm{ml}$ pyridine and $2.0 \mathrm{ml}$ acetic anhydride and incubated for $1 \mathrm{~h}$ at $100^{\circ} \mathrm{C}$. Following the removal of the solvent in vacuo at $40{ }^{\circ} \mathrm{C}$, the peracetylated sugar alditols were dissolved in dichloromethane (DCM) and washed with $3 \times 1.5 \mathrm{ml}$ water. Aliquots of the DCM were then analysed via GLC and by GLC-MS, as described by Oxley, Currie, and Bacic (2004). Total uronides (glucuronic and iduronic acid) were analysed colorimetrically via the method of Bitter and Muir (1962) as modified by Kosakai and Yoshizawa (1979).

Most chemical analyses were conducted in triplicate on dried ground material weighed on a Mettler balance with readability to $0.1 \mathrm{mg}$. Values were reported relative to the dry weight of the seaweed or relative to some analysed fraction.

\subsection{Statistical analysis}

Triplicate analytical determinations of the different MSS samples were submitted to a one-way analysis of variance (ANOVA, SPSS, Version 13.0) followed, if applicable, by a Tukey's multiple means comparison test $(\alpha=0.05)$, which allowed the variability among MSS production batches to be compared to the analytical error. Then we calculated a 95\% confidence interval defined for the three biological replicates of MSS as "mean $\pm 4.3 *$ standard deviation", 4.3 being the Student $t$ table value corresponding to $5 \%$ risk with $3-1=2$ degrees of freedom. LSS determinations were not submitted to statistical testing since there was no biological replication; however, an LSS value being out of the 95\% confidence interval, as defined above, could be a first indication of a substantial variation of the LSS sample with respect to MSS samples.

\section{Results and discussion}

\subsection{Crude protein, ash and dietary fibre}

Ashes, fibre and protein were the most abundant chemical components in this green seaweed (Table 1 ); protein and ash contents ranged $20-26 \%$ and $28-50 \%$ of dry weight (dw), respectively. Analytical precision allowed to distinguish clearly the 3 MSS samples for their crude protein, crude fat and ash contents (Table 1, $P<0.05)$, but their fiber contents were quite similar $(P>0.05)$. Protein content in the LSS sample was inside the $95 \%$ confidence interval defined for MSS samples; in contrast, ash content in the LSS sample (28\%) was much lower than the lower bound of the MSS confidence interval (36\%). Presumably the difference in ash content 
Table 1

Proximal composition and dietary fibre (\% dry weight) of four samples of cultivated U. clathrata.

\begin{tabular}{|c|c|c|c|c|c|c|c|}
\hline Composition & $\mathrm{MSS}_{1}{ }^{\mathrm{B}}$ & MSS2 & MSS3 & $P$ value & Lower bound ${ }^{\mathrm{A}}$ & Upper bound ${ }^{\mathrm{A}}$ & $\mathrm{LSS}^{\mathrm{C}}$ \\
\hline Crude protein & $21.9 \pm 0.1^{\mathrm{a}}$ & $25.9 \pm 0.1^{\mathrm{c}}$ & $23.0 \pm 0.1^{\mathrm{b}}$ & $<0.001$ & 14.7 & 32.5 & $20.1 \pm 0.1$ \\
\hline Crude fat & $2.5 \pm 0.1^{\mathrm{a}}$ & $3.0 \pm 0.1^{\mathrm{b}}$ & $3.5 \pm 0.3^{c}$ & 0.001 & 0.9 & 5.2 & $2.2 \pm 0.1$ \\
\hline Ash & $49.6 \pm 0.2^{c}$ & $44.8 \pm 0.2^{\mathrm{a}}$ & $45.8 \pm 0.3^{b}$ & $<0.001$ & 35.8 & 57.6 & $27.5 \pm 0.2$ \\
\hline $\mathrm{TDF}^{\mathrm{D}}$ & $24.8 \pm 0.2$ & $26.1 \pm 0.5$ & $26.3 \pm 0.9$ & 0.159 & 22.2 & 29.2 & $40.6 \pm 3.0$ \\
\hline $\mathrm{SDF}^{\mathrm{E}}$ & $16.1 \pm 0.4$ & $16.6 \pm 0.2$ & $15.6 \pm 0.1$ & 0.066 & 14.0 & 18.3 & $21.9 \pm 0.9$ \\
\hline $\mathrm{IDF}^{\mathrm{F}}$ & $8.7 \pm 0.6$ & $9.5 \pm 0.8$ & $10.7 \pm 0.1$ & 0.173 & 5.3 & 14.0 & $18.7 \pm 2.1$ \\
\hline SDF/IDF & 1.9 & 1.7 & 1.5 & & & & 1.2 \\
\hline
\end{tabular}

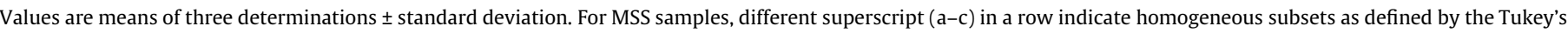
test $(\alpha=0.05)$. $P$ value, significance of an analysis of variance to compare the MSS samples in regard of the analytical error.

A $95 \%$ Confidence interval defined for the three biological replicates of MSS as mean \pm 4.3 st. dev.

B MSS, cultivated $U$. clathrata collected from a medium scale system.

C LSS, cultivated $U$. clathrata collected from a large scale system.

D TDF, total dietary fibre.

E SDF, soluble dietary fibre.

F IDF, insoluble dietary fibre.

is primarily due to the freshwater wash step used when processing the LSS, but not the MSS samples. If the protein content is expressed on an ash free dry basis (assuming that the entire $\mathrm{N}$ measured comes from protein), it amounts to $45 \%$ and $28 \%$ of the MSS and LSS Ulva samples, respectively; thus, a relative reduction in protein content was observed for LSS cultured algae regardless of the loss of ash compounds during the washing and pressing postharvest processes applied to LSS. According to Gómez-Pinchetti, Del Campo Fernández, Moreno-Díez, and García-Reina (1998); Lahaye, Gómez-Pinchetti, Jimenez del Rio, and Garcia-Reina (1995) and Msuya and Neori (2008), the lower $\mathrm{N}$ fertilization in the LSS may explain these differences.

Similar protein but lower ashes values (21.1-29.5\% and 11-29\% dw, respectively) have been reported for $U$. lactuca cultivated in Spain (Ventura \& Castañón, 1998), U. rigida from the Portuguese coast produced as a by-product of a fish farm effluent (Valente et al., 2006), U. lactuca from the coastal area of Northern Chile (Ortiz et al., 2006), from Holbeck, UK (Marsham, Scott, \& Tobin, 2007) and for Enteromorpha prolifera, Enteromorpha linza, and U. fasciata collected and cultivated in India (13.4-22.6 and 6.6-35.6\% dw, respectively) (Naidu et al., 1993). Nevertheless, low protein and high ash values $(5.9-17 \%$ and $17.5-55 \% \mathrm{dw}$ ) have also been reported for the following natural stock samples: $U$. fasciata and $U$. intestinalis (McDermid \& Stuercke, 2003), U. lactuca (Wong \& Cheung, 2000) and for E. intestinalis and Enteromorpha sp sampled on beaches from the city of La Paz, Baja California Sur, México (Aguilera-Morales et al., 2005). In general, protein and ash values reported for wild Ulvales are inversely correlated, and the range of variation is larger than for cultivated seaweeds, which seems related to the degree of variation of environmental conditions. A high inorganic content present in seaweeds is very common and it is due to the extraordinary ability of seaweeds to accumulate elements present in the water where they live (Chapman \& Chapman, 1980). The protein content found in our cultivated $U$. clathrata was comparable with that of protein-rich foods from terrestrial plants such as soya bean.

The TDF, SDF and IDF contents were significantly higher for the LSS sample compared to those in MSS batches, probably due to the lower and less controlled $\mathrm{N}$ fertilization applied to the shrimp pond system. This is in agreement with Lahaye et al. (1995) who reported that the nitrogen content in the culture medium affects the biosynthesis of the algal cell wall polysaccharides as well as of proteins and pigments. Gómez-Pinchetti et al. (1998) also reported, for $U$. rigida, that when nitrogen limits growth, carbohydrate synthesis predominates and in nitrogen enriched conditions, a decrease in fibre content is observed.

TDF values (24.8-40.6\% dw) reported herein for cultivated $U$. clathrata were lower compared to those reported for wild U. lactuca
(55.4\% and 60.5\% dw) by Wong and Cheung (2000) and Ortiz et al. (2006). Nevertheless, TDF contents of the cultivated U. clathrata coincide well with those reported for wild U. lactuca and E. spp. (38.1\% and 33.4\% dw) by Lahaye (1991), and wild and cultivated $U$. rigida (36.9\% to $54.4 \% \mathrm{dw}$ ) reported by Lahaye et al. (1993), 1995) and Gómez-Pinchetti et al. (1998). If the TDF contents are expressed on an ash free dry weight basis, they amount to $49.2 \%, 47.3 \%, 48.5 \%$ and $56 \%$ dw for MSS and LSS U. clathrata cultivated samples; thus, an increase in TDF content is observed for the LSS algae, regardless of the loss of salts eliminated in the postharvest washing and pressing process, it is most likely related to the loss or utilisation of molecules such as protein and reserve metabolites (starch, lipids, etc.).

SDF in $U$. clathrata cultivated samples (16-22\% dw) represented the main fraction of dietary fibre (>50\% of TDF) and, although SDF\% dw was higher for LSS Ulva sample, the soluble to insoluble dietary fibre ratio $(S / I)$ was significantly lower (1.2) for LSS sample vs MSS samples (1.7avg), because the IDF increases at higher rate than the SDF in LSS. In Lahaye et al. (1995) study, growing conditions also affected the $S / I$ ratios. The higher proportion of soluble polysaccharides, in nitrogen enriched $U$. rigida $(S / I=1.23)$ than in wild algae $(S / I=0.93)$, was related to its high growth rate. Rapidly dividing algae produce new cell walls that may contain more matricial polysaccharides with lower self-associating abilities (gelling properties). Gómez-Pinchetti et al. (1998) also analysed tank-cultivated $U$. rigida and observed $S / I$ ratios higher (2.5 to 4.8 ) than those obtained in this work for U. clathrata.

\subsection{Sugars profile}

Many papers have been published on the chemical characterisation of polysaccharides present in Ulva sp. and Enteromorpha sp. (Lahaye, 1991; Lahaye \& Robic, 2007; Lahaye et al., 1995; Ray, 2006), and recently in U. clathrata (Hernández-Garibay, ZertucheGonzález, \& Pacheco-Ruiz, 2011).

Sugar profiles of the four samples of cultivated $U$. clathrata are shown in Table 2. The chemical composition reported herein is in agreement with literature data reported for E. intestinalis (Dodson \& Aroson, 1978), U. lactuca (Lahaye \& Jegou, 1993), U. rigida (Lahaye et al., 1995), and for E. compressa (Lahaye \& Jegou, 1993; Ray, 2006). Ribose was most probably from RNA and ribonucleotides, its presence among the monosaccharides list being the result of an analysis made on the whole algae sample instead of a purified fiber extract. $\mathrm{N}$-acetyl-glucosamine traces were only previously reported for E. intestinalis by Dodson and Aroson (1978), and should be regarded in the present study as a possible contamination of the algal material by crustaceans, since it likely resulted from the degradation of chitin during acid hydrolysis of fibers and sugar derivation for analysis. Uronic acids may include glucuronic and iduronic 
Table 2

Monosacharides profile (\% of total analysed sugars) of four samples of cultivated $U$. clathrata.

\begin{tabular}{|c|c|c|c|c|c|c|c|}
\hline Monossacharides & $\mathrm{MSS}^{\mathrm{B}}$ & MSS2 & MSS3 & $P$ value & Lower bound $^{\mathrm{A}}$ & Upper bound $^{\mathrm{A}}$ & LSS $^{\mathrm{C}}$ \\
\hline Rhamnose & $40.43 \pm 0.51^{\mathrm{c}}$ & $33.94 \pm 0.48^{\mathrm{a}}$ & $35.68 \pm 0.27^{b}$ & $<0.001$ & 22.2 & 51.1 & $39.38 \pm 0.41$ \\
\hline Ribose & $1.76 \pm 0.04^{c}$ & $1.18 \pm 0.06^{\mathrm{a}}$ & $1.31 \pm 0.03^{b}$ & $<0.001$ & 0.1 & 2.7 & $0.55 \pm 0.02$ \\
\hline Fucose & $0.32 \pm 0.01^{\mathrm{a}}$ & $0.33 \pm 0.03^{\mathrm{ab}}$ & $0.36 \pm 0.02^{b}$ & 0.042 & 0.2 & 0.4 & $0.27 \pm 0.01$ \\
\hline Arabidose & $0.29 \pm 0.01$ & $0.27 \pm 0.02$ & $0.33 \pm 0.04$ & 0.07 & 0.2 & 0.4 & $0.21 \pm 0.01$ \\
\hline Xylose & $10.22 \pm 0.14^{\mathrm{a}}$ & $11.08 \pm 0.18^{\mathrm{b}}$ & $10.83 \pm 0.07^{b}$ & 0.001 & 8.8 & 12.6 & $12.91 \pm 0.20$ \\
\hline Mannose & $1.56 \pm 0.05^{\mathrm{a}}$ & $2.21 \pm 0.05^{\mathrm{b}}$ & $2.52 \pm 0.05^{c}$ & $<0.001$ & 0.0 & 4.2 & $1.37 \pm 0.02$ \\
\hline Glucose & $9.77 \pm 0.11^{a}$ & $15.62 \pm 0.23^{c}$ & $13.02 \pm 0.12^{b}$ & $<0.001$ & 0.2 & 25.4 & $13.98 \pm 0.21$ \\
\hline Galactose & $7.66 \pm 0.10^{a}$ & $7.87 \pm 0.14^{\mathrm{ab}}$ & $7.95 \pm 0.04^{\mathrm{b}}$ & 0.032 & 7.2 & 8.5 & $4.86 \pm 0.06$ \\
\hline Uronic acids & $27.72 \pm 0.85$ & $27.05 \pm 1.12$ & $27.39 \pm 0.50$ & 0.656 & 25.9 & 28.8 & $26.12 \pm 0.90$ \\
\hline $\mathrm{N}$-acetyl-glucosamine & $0.28 \pm 0.01^{\mathrm{a}}$ & $0.44 \pm 0.01^{\mathrm{b}}$ & $0.61 \pm 0.01^{\mathrm{c}}$ & $<0.001$ & -0.3 & 1.2 & $0.36 \pm 0.02$ \\
\hline Total & $20.82 \pm 0.22^{\mathrm{a}}$ & $20.73 \pm 0.28^{\mathrm{a}}$ & $19.74 \pm 0.16^{\mathrm{b}}$ & 0.002 & 17.8 & 23.0 & $24.23 \pm 6.88$ \\
\hline
\end{tabular}

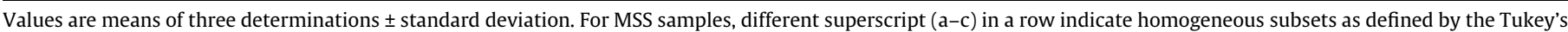
test $(\alpha=0.05)$. $P$ value, anova significance.

A $95 \%$ confidence interval defined for the three biological replicates of MSS.

B MSS, cultivated $U$. clathrata collected from a medium scale system.

C LSS, cultivated $U$. clathrata collected from a large scale system.

acids, as part of ulvanobiouronic 3-sulphate type $A$ (A3s) and type B (B3s) respectively, described by Lahaye (2001) and Lahaye and Robic (2007) for green seaweeds ulvan; Hernandez-Garibay et al. (2011) were not able to identify the exact proportions of glucuronic and iduronic acids, but concluded that the fractions obtained from $U$. clathrata were deviants of the A3s and B3s ulvanobiuronic acids. Total content of analysed monosaccharides reflected TDF with an average $5 \%$ difference probably related to sulphates; considering an ulvan yield range of $8-29 \%$ from algal dry weight, and a sulphate proportion of $16-23 \%$ in ulvan (Lahaye \& Robic, 2007), sulphate content in algal dry matter could vary from 1$7 \%$, this range being compatible with the observed difference between TDF and total monosaccharides. On a percentage basis of the dry algae, LSS sample resulted with a slightly higher content of total monosaccharides. On a percentage basis of the total sugar analysed, LSS sample contained less galactose than the MSS samples, while uronic acids and other sugar proportions remained close regardless of the growing system.

Ray (2006) indicated that yields and sugar compositions of fractions obtained from Ulvales of different places are quite different when comparing in molar base. But, it is well known that seasonal variations and changes in $\mathrm{pH}$, temperature, etc. of places from which the algae were collected, or else the experimental growing conditions used in culture, are responsible for the variation of their compositions (Lahaye, 1991; Lahaye et al., 1995; Ray, 2006).

\subsection{Amino acids}

The amino acid (AA) composition of cultivated $U$. clathrata samples is presented in Table 3. The aspartic acid and glutamic acid were the most abundant AAs, representing up to $24 \%$ of the total

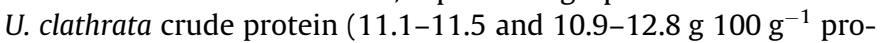
tein respectively) with close values for MSS and LSS samples. This agrees with observations by other authors for other Ulva and Enteromorpha species (Ortiz et al., 2006; Taboada, Millán, \& Míguez, 2009; Wong \& Cheung, 2000). According to Mabeau and Fleurence (1993), the high levels of aspartic and glutamic acids are responsible for the special flavour and taste of the seaweed.

Alanine and arginine are the second AA group found in high lev-

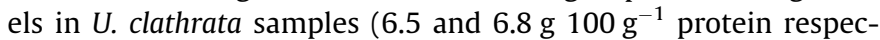
tively). The extraordinary arginine richness of $U$. clathrata protein does not appear to be common for all Ulvales; this characteristic only coincides with AA analysis values reported for $U$. pertusa (Fujiwara-Arasaki et al., 1984, cited in Fleurence, 1999), U. lactuca (Wong \& Cheung, 2000) and U. rigida (Taboada et al., 2009).
Other essential amino acids (EAA), such as leucine, valine, phenylalanine, threonine, serine, were also found in high concentrations.

The $U$. clathrata sample grown in the LSS contains about $30 \%$ more threonine, alanine, and total sulphur containing AA (cysteine and methionine), than the MSS sample. This is particularly interesting from a nutritional point of view considering that methionine and cysteine frequently are growth limiting AAs in animal feeds. In general, AAs proportions in the crude protein of the LSS sample were close to the upper bound of the $95 \%$ confidence interval as defined for the MSS samples, and even surpassed it in the cases of taurine, $\mathrm{OH}$-proline, threonine, serine, alanine, $\mathrm{OH}$-lysine, leading to a consistent difference in total AA yield per $100 \mathrm{~g}$ crude protein (i.e. sum of AAs $/(\mathrm{N} \times 6.25) * 100)$ between MSS and LSS samples (78.4\% and 90\%). Gómez-Pinchetti et al. (1998) mentioned that excess nitrogen, as well as other nutrients, can be stored and used for growth during limited periods by some macroalgae including Ulvales. Storage occurs as inorganic nitrogen $\left(\mathrm{NO}_{3}^{-}\right.$and $\left.\mathrm{NH}_{4}^{+}\right)$and organic compounds, amino acids and proteins. Similar AAs yields were found for $U$. lactuca ( $89 \%$ of crude protein) by Wong and Cheung (2000) and for U. rigida (78\%) by Taboada et al. (2009).

All samples were rich in EAAs, which sum ranged $40-42 \%$ of total analysed AAs, and was consistent with data obtained in previous studies in U. lactuca and Enteromorpha spp. (Aguilera-Morales et al., 2005; Wong \& Cheung, 2000). EAA/NEAA ratio values were significantly higher in MSS samples (0.71-0.73) than in LSS sample (0.66). These ratios were lower than $U$. rigida EAA/NEAA ratio (1.0) reported by Taboada et al. (2009).

\subsection{Lipids and fatty acids}

The total lipid (TL) content in all $U$. clathrata samples was low (<3.5). LSS sample presented less TL than MSS samples $(2.2 \%$ vs $3 \% \mathrm{dw}$ ), but remained well inside the $95 \%$ confidence interval as defined for MSS samples (0.9-5.2\%). These values fall within the range already reported for different Ulva species (0.2-5.6\%) (Aguilera-Morales et al., 2005; Kumar et al. 2010; Kumari, Kumar, Gupta, Reddy, \& Jha, 2010; Marsham et al., 2007; McDermid \& Stuercke, 2003; Ortiz et al., 2006; Taboada et al., 2009; Valente et al., 2006; Ventura \& Castañón, 1998; Wong \& Cheung, 2000).

The fatty acid (FA) composition of Ulva samples is shown in Table 4. In general, the four samples analysed had a characteristic FA profile of Ulvales with high C18 polyunsaturated fatty acids (PUFA) contents (Kumari et al., 2010). High amounts of linoleic (7.35$9.74 \%$ of total fat) and linolenic acid (3.92-14.6\% of total fat) were found, these values being similar to those reported by Cruz-Suárez 
Table 3

Amino acid composition ( $\mathrm{g}$ amino acid $100 \mathrm{~g}^{-1}$ protein) of four samples of cultivated $U$. clathrat.

\begin{tabular}{|c|c|c|c|c|c|c|c|}
\hline Amino acids & $\mathrm{MSS}^{\mathrm{B}}$ & MSS2 & MSS3 & $P$ value & Lower bound $^{\mathrm{A}}$ & Upper bound $^{A}$ & LSS $^{\mathrm{C}}$ \\
\hline Tau & $0.45 \pm 0.06$ & $0.43 \pm 0.04$ & $0.48 \pm 0.05$ & 0.475 & 0.3 & 0.6 & $0.64 \pm 0.06$ \\
\hline Hyp & $1.38 \pm 0.17$ & $1.35 \pm 0.06$ & $1.32 \pm 0.15$ & 0.878 & 1.2 & 1.5 & $2.39 \pm 0.08$ \\
\hline Asp & $11.47 \pm 0.21$ & $11.05 \pm 0.32$ & $11.32 \pm 0.15$ & 0.177 & 10.4 & 12.2 & $11.14 \pm 0.08$ \\
\hline Thr & $3.49 \pm 0.1^{\mathrm{a}}$ & $3.44 \pm 0.08^{\mathrm{a}}$ & $3.78 \pm 0.05^{b}$ & 0.004 & 2.8 & 4.4 & $4.59 \pm 0.10$ \\
\hline Ser & $3.31 \pm 0.21$ & $3.22 \pm 0.16$ & $3.33 \pm 0.19$ & 0.784 & 3.0 & 3.5 & $4.69 \pm 0.27$ \\
\hline Glu & $11.56 \pm 0.18$ & $11.54 \pm 0.57$ & $10.93 \pm 0.43$ & 0.203 & 9.8 & 12.9 & $12.8 \pm 0.32$ \\
\hline Pro & $2.66 \pm 0.02^{\mathrm{b}}$ & $2.49 \pm 0.06^{\mathrm{a}}$ & $2.89 \pm 0.05^{c}$ & $<0.001$ & 1.8 & 3.5 & $2.85 \pm 0.03$ \\
\hline Gly & $4.59 \pm 0.05^{\mathrm{a}}$ & $4.47 \pm 0.09^{a}$ & $5.02 \pm 0.09^{b}$ & $<0.001$ & 3.4 & 5.9 & $5.8 \pm 0.04$ \\
\hline Ala & $6.35 \pm 0.11^{\mathrm{a}}$ & $6.28 \pm 0.15^{\mathrm{a}}$ & $6.85 \pm 0.14^{\mathrm{b}}$ & 0.004 & 5.2 & 7.8 & $8.64 \pm 0.05$ \\
\hline Cys & $1.68 \pm 0.01^{\mathrm{b}}$ & $1.46 \pm 0.06^{\mathrm{a}}$ & $1.54 \pm 0.05^{\mathrm{a}}$ & 0.003 & 1.1 & 2.0 & $1.99 \pm 0.03$ \\
\hline Val & $4.41 \pm 0.02^{\mathrm{a}}$ & $4.20 \pm 0.08^{\mathrm{a}}$ & $4.84 \pm 0.11^{\mathrm{c}}$ & $<0.001$ & 3.1 & 5.9 & $5.55 \pm 0.10$ \\
\hline Met & $1.16 \pm 0.03^{\mathrm{a}}$ & $1.14 \pm 0.05^{\mathrm{a}}$ & $1.3 \pm 0.01^{\mathrm{b}}$ & 0.001 & 0.8 & 1.6 & $1.56 \pm 0.01$ \\
\hline Ile & $2.73 \pm 0.02^{\mathrm{a}}$ & $2.66 \pm 0.04^{\mathrm{a}}$ & $3.13 \pm 0.09^{b}$ & $<0.001$ & 1.7 & 3.9 & $3.26 \pm 0.08$ \\
\hline Leu & $4.61 \pm 0.05^{a}$ & $4.53 \pm 0.11^{\mathrm{a}}$ & $5.35 \pm 0.09^{b}$ & $<0.001$ & 2.9 & 6.8 & $4.99 \pm 0.04$ \\
\hline Tyr & $1.74 \pm 0.05^{\mathrm{a}}$ & $1.68 \pm 0.06^{\mathrm{a}}$ & $1.95 \pm 0.03^{b}$ & 0.001 & 1.2 & 2.4 & $1.79 \pm 0.06$ \\
\hline Phe & $3.69 \pm 0.05^{\mathrm{a}}$ & $3.68 \pm 0.07^{a}$ & $4.20 \pm 0.09^{b}$ & $<0.001$ & 2.6 & 5.1 & $4.41 \pm 0.04$ \\
\hline Hyl & $0.58 \pm 0.03$ & $0.58 \pm 0.02$ & $0.58 \pm 0.01$ & 0.976 & 0.6 & 0.6 & $1.37 \pm 0.03$ \\
\hline Orn & $0.14 \pm 0.03^{\mathrm{a}}$ & $0.18 \pm 0.02^{\mathrm{a}}$ & $0.27 \pm 0.03^{b}$ & 0.003 & -0.1 & 0.5 & $0.46 \pm 0.01$ \\
\hline Lys & $3.27 \pm 0.05^{\mathrm{b}}$ & $3.01 \pm 0.05^{\mathrm{a}}$ & $3.39 \pm 0.03^{c}$ & $<0.001$ & 2.4 & 4.1 & $3.61 \pm 0.10$ \\
\hline His & $1.21 \pm 0.04^{\mathrm{b}}$ & $1.09 \pm 0.03^{\mathrm{a}}$ & $1.24 \pm 0.03^{b}$ & 0.003 & 0.8 & 1.5 & $0.98 \pm 0.01$ \\
\hline $\operatorname{Arg}$ & $7.24 \pm 0.14^{\mathrm{b}}$ & $7.29 \pm 0.15^{\mathrm{b}}$ & $6.09 \pm 0.08^{\mathrm{a}}$ & $<0.001$ & 4.0 & 9.8 & $6.21 \pm 0.10$ \\
\hline Trp & $0.67 \pm 0.04$ & $0.61 \pm 0.03$ & $0.66 \pm 0.03$ & 0.116 & 0.5 & 0.8 & $0.58 \pm 0.01$ \\
\hline Total & $78.40 \pm 1.19^{\mathrm{ab}}$ & $76.39 \pm 1.99^{a}$ & $80.45 \pm 1.04^{\mathrm{b}}$ & 0.04 & 69.7 & 87.1 & $90.31 \pm 0.96$ \\
\hline $\mathrm{EAA}^{\mathrm{D}}$ & $32.49 \pm 0.46^{\mathrm{a}}$ & $31.65 \pm 0.54^{\mathrm{a}}$ & $33.98 \pm 0.46^{\mathrm{b}}$ & 0.003 & 27.6 & 37.8 & $35.74 \pm 0.33$ \\
\hline $\mathrm{NEAA}^{\mathrm{E}}$ & $45.91 \pm 0.77$ & $44.73 \pm 1.47$ & $46.47 \pm 0.68$ & 0.192 & 41.9 & 49.5 & $54.56 \pm 0.67$ \\
\hline EAA/NEAA & $0.71: 1 \pm 0.01^{\mathrm{a}}$ & $0.71: 1 \pm 0.01^{\mathrm{a}}$ & $0.73: 1 \pm 0.01^{b}$ & 0.03 & 0.7 & 0.8 & $0.66: 1 \pm 0.01$ \\
\hline
\end{tabular}

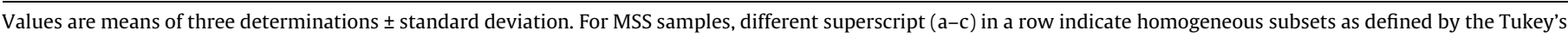
test $(\alpha=0.05)$. $P$ value, anova significance.

A $95 \%$ confidence interval defined for the three biological replicates of MSS.

${ }^{\text {B }}$ MSS, cultivated $U$. clathrata collected from a medium scale system.

C LSS, cultivated $U$. clathrata collected from a large scale system.

D EAA, essential amino acids: Thr, Val, Met, Ile, Leu, Phe, Lys, His, Arg and Trp.

E NEAA, non-essential amino acids.

et al. (2010); nevertheless LSS sample presented lower concentration for both FA, especially the linolenic acid, which content was about one third compared to MSS samples, and well below the inferior limit of the 95\% confidence interval for MSS. Linoleic acid content values found in U. clathrata LSS samples were consistent with those reported by Kumari et al. (2010) for seven Ulva species (7.6-11.7\%). In contrast, linolenic acid content, in MSS U. clathrata, was much higher (7-fold) (13.25-14.60\%) than Kumari's values for other Ulvales ( 0.95 to 2.25 ). The sum of saturated fatty acids (SFA) was significantly higher in the LSS sample, and reflected the higher concentration of palmitic acid in this sample (38.5\% of total fat). $U$. clathrata samples presented lower SFA values (30-51\%) than Ulvales (51-64\%) reported by Kumari et al. (2010). Total monounsaturated fatty acids concentrations (MUFA) were similar among samples with values between $10.2 \%$ and $12.4 \%$ of total fat, and congruent with the value (9.2\%) previously reported in a shrimp and $U$. clathrata co-culture study (Cruz-Suárez et al., 2010) and the values (14.7-26.1) reported by Kumari et al. (2010). Total polyunsaturated fatty acids (PUFAs) concentrations for MSS samples were similar to the value (34\%) reported by Cruz-Suárez et al. (2010), while the LSS sample showed a much lower concentration (13.1\%) that falls in the range of Kumari's reported values (14.729.1\%). Total n6 PUFAs in all samples ranged from $7.96-12.46 \%$ of total fat, which is congruent with the 9.6\% linoleic acid (C18:2n-6) content found by Cruz-Suárez et al. (2010), and similar to the concentration shown for other Ulvales (Aguilera-Morales et al., 2005). The n3 PUFA values found for MSS samples (19-23\% of total fat) were higher compared to some previous reports (Aguilera-Morales et al., 2005; Ortiz et al., 2006), but slightly inferior to a total of $24.7 \%$ for n6 PUFAs as reported by Cruz-Suárez et al. (2010); in contrast, the value was much lower in the LSS sample (5.2\%). The n6/n3 PUFA ratio ranged from 0.5 to 0.6 in the case of MSS samples to 1.5 for LSS, the latter value was similar to those re- ported for other Ulvales (1.42-3.03) (Kumari et al., 2010; Ortiz et al., 2006). High n-3 PUFAs content is an important feature of Ulva products, which has been used, for example, to improve egg quality through n3 PUFAs enrichment by feeding leghorn hens with a diet supplemented with sardine oil and Enteromorpha spp. (Carrillo et al., 2008). Although $U$. clathrata presented low lipid content, its high PUFA content is superior to those of the terrestrial vegetables and indicates its potential utilisation in preparation of human foods.

\subsection{Total carotenoids}

Xanthophylls ranged $10.2-35.2 \mathrm{mg} \mathrm{kg}^{-1}$ with the lower value for LSS, while variability was high amongst MSS samples (Table 5). Total carotenoids in MSS samples (250-441 $\mathrm{mg} \mathrm{kg}^{-1}$ ) were also higher than in LSS sample ( $\left.169 \mathrm{mg} \mathrm{kg}^{-1}\right)$, this range being comparable to that presented in carrots or fruits as papaya and mango (Yahia, Ramírez-Padilla, \& Carrillo-López, 2009). Lutein, a main carotenoid present in Ulva, and well known as an eye and skin health promoter (Lewis, 2008), has been proven to be a good source for shrimp pigmentation (Cruz-Suárez et al., 2010). It is important to point out that carotenoid levels can be strongly influenced by drying and storage. Low levels in the LSS sample are more likely to be a result of non-optimal drying and storage than a true reflection of carotenoid levels before harvest.

\subsection{Minerals concentrations}

Mineral concentrations analysed in $U$. clathrata samples are summarised in Table 6. A wide variation in mineral content was observed among samples. A higher Ca content was observed in Ulva produced in shrimp ponds (LSS samples) than MSS samples (average 10 vs $19 \mathrm{~g} \mathrm{~kg}^{-1} \mathrm{dw}$ ). Nevertheless, Ca content in 
Table 4

Fatty acid composition (\% of total fat) of four samples of cultivated U. clathrata.

\begin{tabular}{|c|c|c|c|c|c|c|c|}
\hline Fatty acids & $\mathrm{MSS1}^{\mathrm{B}}$ & MSS2 & MSS3 & $P$ value & Lower bound ${ }^{\mathrm{A}}$ & Upper bound $^{\mathrm{A}}$ & LSS $^{\mathrm{C}}$ \\
\hline $\mathrm{C} 8: 0$ & $0.11 \pm 0.04^{b}$ & $0.04 \pm 0.01^{\mathrm{ab}}$ & $0.03 \pm 0.03^{\mathrm{a}}$ & 0.026 & -0.1 & 0.2 & $0.06 \pm 0.10$ \\
\hline C10:0 & $0.01 \pm 0.02^{\mathrm{a}}$ & n.d. & $0.40 \pm 0.02^{\mathrm{b}}$ & $<0.001$ & -0.8 & 1.1 & $0.60 \pm 1.05$ \\
\hline $\mathrm{C} 12: 0$ & $1.44 \pm 0.1^{\mathrm{a}}$ & $1.56 \pm 0.05^{\mathrm{ab}}$ & $1.74 \pm 0.10^{\mathrm{b}}$ & 0.013 & 0.9 & 2.2 & $2.14 \pm 0.02$ \\
\hline C13:0 & $0.99 \pm 0.04$ & $0.96 \pm 0.07$ & $1.03 \pm 0.04$ & 0.267 & 0.8 & 1.2 & $1.38 \pm 0.04$ \\
\hline $\mathrm{C} 14: 0$ & $0.58 \pm 0.06$ & $0.64 \pm 0.14$ & $0.82 \pm 0.15$ & 0.124 & 0.2 & 1.2 & $0.95 \pm 0.14$ \\
\hline $\mathrm{C} 14: 1_{9 \mathrm{c}}$ & $1.40 \pm 0.03^{\mathrm{a}}$ & $1.67 \pm 0.12^{b}$ & $1.81 \pm 0.13^{\mathrm{b}}$ & 0.008 & 0.7 & 2.5 & $1.7 \pm 0.01$ \\
\hline $\mathrm{C} 15: 0$ & $0.20 \pm 0.01$ & $0.24 \pm 0.09$ & $0.31 \pm 0.07$ & 0.209 & 0.0 & 0.5 & $0.35 \pm 0.03$ \\
\hline $\mathrm{C} 16: 0$ & $26.53 \pm 0.26^{\mathrm{b}}$ & $23.64 \pm 0.32^{\mathrm{a}}$ & $24.19 \pm 0.35^{\mathrm{a}}$ & $<0.001$ & 18.2 & 31.4 & $38.46 \pm 0.51$ \\
\hline $\mathrm{C} 16: 1_{9 \mathrm{c}}$ & $0.64 \pm 0.05^{\mathrm{a}}$ & $0.97 \pm 0.02^{\mathrm{b}}$ & $1.39 \pm 0.09^{c}$ & $<0.001$ & -0.6 & 2.6 & $1.46 \pm 0.01$ \\
\hline $\mathrm{C} 17: 0$ & $0.08 \pm 0.01^{\mathrm{a}}$ & $0.20 \pm 0.04^{\mathrm{b}}$ & $0.29 \pm 0.06^{\mathrm{b}}$ & 0.001 & -0.3 & 0.7 & $0.36 \pm 0.01$ \\
\hline $\mathrm{C} 17: 1_{10 c}$ & $0.59 \pm 0.01^{\mathrm{a}}$ & $0.91 \pm 0.04^{\mathrm{b}}$ & $0.92 \pm 0.02^{\mathrm{b}}$ & $<0.001$ & 0.0 & 1.6 & $0.75 \pm 0.11$ \\
\hline $\mathrm{C} 18: 0$ & $0.44 \pm 0.01^{\mathrm{a}}$ & $0.57 \pm 0.13^{a}$ & $0.84 \pm 0.09^{\mathrm{b}}$ & 0.005 & -0.3 & 1.5 & $1.41 \pm 0.07$ \\
\hline C18:19t & $1.85 \pm 0.01^{\mathrm{a}}$ & $2.82 \pm 0.04^{b}$ & $2.76 \pm 0.04^{\mathrm{b}}$ & $<0.001$ & 0.1 & 4.8 & $1.19 \pm 0.03$ \\
\hline C18:19c & $0.89 \pm 0.15^{\mathrm{a}}$ & $1.54 \pm 0.08^{\mathrm{b}}$ & $2.02 \pm 0.02^{\mathrm{C}}$ & $<0.001$ & -0.9 & 3.9 & $2.19 \pm 0.10$ \\
\hline $\mathrm{C} 18: 1_{11 \mathrm{c}}$ & $4.78 \pm 0.04^{b}$ & $3.58 \pm 0.08^{\mathrm{a}}$ & $3.52 \pm 0.06^{\mathrm{a}}$ & $<0.001$ & 0.9 & 7.0 & $4.89 \pm 0.08$ \\
\hline $\mathrm{C} 18: 2_{\mathrm{n} 6}$ & $8.44 \pm 0.14^{\mathrm{a}}$ & $9.74 \pm 0.24^{b}$ & $8.69 \pm 0.24^{\mathrm{a}}$ & 0.001 & 6.0 & 11.9 & $7.35 \pm 0.10$ \\
\hline C20:0 & $0.28 \pm 0.03$ & $0.25 \pm 0.04$ & $0.23 \pm 0.01$ & 0.184 & 0.2 & 0.4 & $0.82 \pm 0.02$ \\
\hline $\mathrm{C} 18: 3 \gamma_{\mathrm{n} 6}$ & $0.73 \pm 0.02^{c}$ & $0.60 \pm 0.02^{\mathrm{b}}$ & $0.51 \pm 0.02^{\mathrm{a}}$ & $<0.001$ & 0.1 & 1.1 & $0.11 \pm 0.01$ \\
\hline $\mathrm{C} 18: 3_{\mathrm{n} 3}$ & $14.30 \pm 0.09^{\mathrm{b}}$ & $14.60 \pm 0.28^{\mathrm{b}}$ & $13.25 \pm 0.27^{\mathrm{a}}$ & 0.001 & 11.0 & 17.1 & $3.92 \pm 0.07$ \\
\hline $\mathrm{C} 20: 1_{\mathrm{n} 9}$ & n.d. ${ }^{I}$ & n.d. & n.d. & n.d. & & & $0.19 \pm 0.01$ \\
\hline $\mathrm{C} 18: 4_{\mathrm{n} 3}$ & $5.01 \pm 0.05^{c}$ & $3.79 \pm 0.11^{b}$ & $3.15 \pm 0.09^{\mathrm{a}}$ & $<0.001$ & -0.1 & 8.0 & $0.66 \pm 0.10$ \\
\hline $\mathrm{C} 22: 0$ & $2.30 \pm 0.03^{c}$ & $1.52 \pm 0.03^{b}$ & $1.44 \pm 0.02^{\mathrm{a}}$ & $<0.001$ & -0.3 & 3.8 & $3.94 \pm 0.09$ \\
\hline $\mathrm{C} 20: 3 \gamma_{\mathrm{n} 6}$ & $0.94 \pm 0.01^{\mathrm{b}}$ & $0.84 \pm 0.02^{\mathrm{a}}$ & $0.83 \pm 0.02^{\mathrm{a}}$ & $<0.001$ & 0.6 & 1.1 & n.d. \\
\hline $\mathrm{C} 20: 4_{\mathrm{n} 6}$ & $0.69 \pm 0.03^{a}$ & $0.84 \pm 0.02^{\mathrm{b}}$ & $0.83 \pm 0.02^{\mathrm{b}}$ & $<0.001$ & 0.4 & 1.1 & $0.39 \pm 0.01$ \\
\hline $\mathrm{C} 20: 4_{\mathrm{n} 3}$ & $0.56 \pm 0.01^{c}$ & $0.46 \pm 0.02^{b}$ & $0.42 \pm 0.01^{\mathrm{a}}$ & $<0.001$ & 0.2 & 0.8 & $0.12 \pm 0.01$ \\
\hline $\mathrm{C} 20: 5_{\mathrm{n} 3}$ & $1.28 \pm 0.06^{\mathrm{a}}$ & $1.41 \pm 0.03^{b}$ & $1.39 \pm 0.05^{\mathrm{ab}}$ & 0.026 & 1.1 & 1.7 & $0.33 \pm 0.01$ \\
\hline $\mathrm{C} 24: 0$ & $0.12 \pm 0.12$ & $0.03 \pm 0.05$ & n.d. & 0.216 & -0.2 & 0.3 & $0.56 \pm 0.02$ \\
\hline $\mathrm{C} 22: 4_{\mathrm{n} 6}$ & $0.63 \pm 0.02^{\mathrm{b}}$ & $0.45 \pm 0.02^{\mathrm{a}}$ & $0.44 \pm 0.02^{\mathrm{a}}$ & $<0.001$ & 0.0 & 1.0 & $0.11 \pm 0.01$ \\
\hline $\mathrm{C} 22: 5_{\mathrm{n} 3}$ & $1.74 \pm 0.02^{c}$ & $1.02 \pm 0.03^{b}$ & $0.93 \pm 0.03^{\mathrm{a}}$ & $<0.001$ & -0.7 & 3.1 & $0.12 \pm 0.01$ \\
\hline$\sum \mathrm{SFA}^{\mathrm{D}}$ & $33.09 \pm 0.14^{\mathrm{c}}$ & $29.64 \pm 0.10^{\mathrm{a}}$ & $31.33 \pm 0.10^{\mathrm{b}}$ & $<0.001$ & 23.9 & 38.8 & $51.04 \pm 1.09$ \\
\hline$\sum \mathrm{MUFA}^{\mathrm{E}}$ & $10.15 \pm 0.21^{\mathrm{a}}$ & $11.49 \pm 0.12^{\mathrm{b}}$ & $12.41 \pm 0.10^{c}$ & $<0.001$ & 6.5 & 16.2 & $12.37 \pm 0.12$ \\
\hline$\sum$ PUFA $^{\mathrm{F}}$ & $34.32 \pm 0.38^{\mathrm{b}}$ & $33.75 \pm 0.70^{\mathrm{b}}$ & $30.43 \pm 0.72^{\mathrm{a}}$ & 0.001 & 23.8 & 41.9 & $13.11 \pm 0.19$ \\
\hline$\sum \mathrm{n} 6-\mathrm{FA}^{\mathrm{G}}$ & $11.44 \pm 0.20^{\mathrm{a}}$ & $12.46 \pm 0.30^{\mathrm{b}}$ & $11.29 \pm 0.29^{\mathrm{a}}$ & 0.003 & 9.0 & 14.5 & $7.96 \pm 0.11$ \\
\hline$\sum \mathrm{n} 3-\mathrm{FA}^{\mathrm{H}}$ & $22.89 \pm 0.18^{c}$ & $21.29 \pm 0.45^{\mathrm{b}}$ & $19.14 \pm 0.44^{\mathrm{a}}$ & $<0.001$ & 13.0 & 29.2 & $5.15 \pm 0.08$ \\
\hline$\sum \mathrm{n} 6 / \sum \mathrm{n} 3$ & $0.5: 1 \pm 0.01^{\mathrm{a}}$ & $0.6: 1 \pm 0.01^{\mathrm{b}}$ & $0.6: 1 \pm 0.01^{\mathrm{b}}$ & $<0.001$ & 0.3 & 0.8 & $1.5: 1 \pm 0.01$ \\
\hline
\end{tabular}

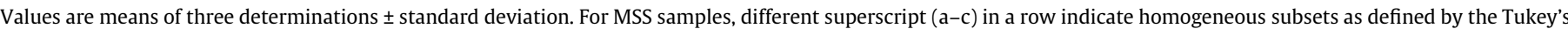
test $(\alpha=0.05)$. $P$ value, anova significance.

A $95 \%$ confidence interval defined for the three biological replicates of MSS.

B MSS, cultivated $U$. clathrata collected from a medium scale system.

C LSS, cultivated $U$. clathrata collected from a large scale system.

D $\sum$ SFA, total saturated fatty acids.

E $\sum$ MUFA, total monounsaturated fatty acids.

F $\sum$ PUFA, total polyunsaturated fatty acids.

G $\sum$ n6-FA, total Omega-6 fatty acids.

H $\sum n 3-F A$, total Omega-3 fatty acids.

I n.d., not determined.

Table 5

Carotenoids content $\left(\mathrm{mg} \mathrm{kg}^{-1} \mathrm{dw}\right.$ ) of four samples of cultivated $U$. clathrata.

\begin{tabular}{|c|c|c|c|c|c|c|c|}
\hline & $\mathrm{MSS1}^{\mathrm{B}}$ & MSS2 & MSS3 & $P$ value & Lower bound $^{\mathrm{A}}$ & Upper bound $^{\mathrm{A}}$ & $\mathrm{LSS}^{\mathrm{C}}$ \\
\hline Xanthophylls & $23.3 \pm 11.0$ & $16.3 \pm 3.3$ & $35.2 \pm 13.5$ & 0.153 & -16 & 66 & $10.2 \pm 5.2$ \\
\hline Carotenoids & $294.5 \pm 9.0^{\mathrm{a}}$ & $338.4 \pm 8.5^{\mathrm{b}}$ & $440.7 \pm 18.7^{\mathrm{c}}$ & $<0.001$ & 35 & 680 & $169.4 \pm 1.3$ \\
\hline
\end{tabular}

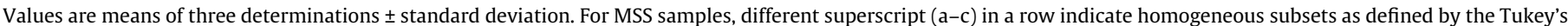
test $(\alpha=0.05)$. $P$ value, anova significance.

A $95 \%$ confidence interval defined for the three biological replicates of MSS.

B MSS, cultivated $U$. clathrata collected from a medium scale system.

c LSS, cultivated $U$. clathrata collected from a large scale system.

cultivated $U$. clathrata was lower than those reported for E. intestinalis ( 25 to $122 \mathrm{~g} \mathrm{Ca} \mathrm{kg}^{-1}$ ) collected in the La Paz bay and lagoon in Baja California México (Rodríguez-Castañeda, Sánchez-Rodríguez, Shumilin, \& Sapozzhnikov, 2006) and also lower than values reported by Kumar et al. (2010) for other ulvales ( 26 to $47 \mathrm{~g} \mathrm{Ca} \mathrm{kg}^{-1}$ ). Among the microelements presents in the U. clathrata samples, Fe was the most abundant followed by $\mathrm{Zn}, \mathrm{Cu}, \mathrm{As}, \mathrm{Ni}, \mathrm{Pb}, \mathrm{Cr}$ and $\mathrm{Cd}$. The content of these microelements presented significant differences among the 3 MSS samples. Furthermore, Fe, As and Ni contents were higher in Ulva produced in earthen ponds (LSS) than in laboratory produced samples (MSS). However, Fe contents $\left(0.3-4.2 \mathrm{~g} \mathrm{~kg}^{-1} \mathrm{dw}\right)$ in our cultivated $U$. clathrata samples were similar to those reported $\left(0.27-4 \mathrm{~g} \mathrm{~kg}^{-1} \mathrm{dw}\right)$ for wild Enteromorpha clathrata and other ulvales collected from the subtropical Pacific coast of México (Paez-Osuna, Ochoa-Izaguirre, Bojorquez-Leyva, \& Michel-Reynoso, 2000) and lower than those reported for E. intestinalis (7-14 $\mathrm{g} \mathrm{Fe} \mathrm{kg}^{-1}$ ) collected in La Paz Bay, Mexico by Rodríguez-Castañeda et al. (2006), or similar, only in the case of MSS samples $\left(0.3-0.8 \mathrm{~g} \mathrm{~kg}^{-1} \mathrm{dw}\right)$, to those concentrations $\left(0.12-0.72 \mathrm{~g} \mathrm{Fe} \mathrm{kg}^{-1}\right)$ reported by Mohamed and Khaled (2005) in 
Table 6

Metal concentration ( $\mathrm{mg} \mathrm{kg}^{-1} \mathrm{dw}$ ) of four samples of cultivated U. clathrata.

\begin{tabular}{|c|c|c|c|c|c|c|c|}
\hline Element & $\mathrm{MSS}^{\mathrm{B}}$ & MSS2 & MSS3 & $P$ value & Lower bound $^{\mathrm{A}}$ & Upper bound ${ }^{\mathrm{A}}$ & LSS $^{\mathrm{C}}$ \\
\hline Calcium $\left(\times 10^{3}\right)$ & $9.05 \pm 0.01^{\mathrm{a}}$ & $11.39 \pm 0.29^{b}$ & $8.85 \pm 0.23^{a}$ & $<0.001$ & 0.4 & 1.6 & $18.80 \pm 6.70$ \\
\hline Iron & $340.1 \pm 5.9^{\mathrm{a}}$ & $786.2 \pm 14.0^{c}$ & $737.6 \pm 157.9$ & $<0.001$ & 7.6 & 81.1 & $4172 \pm 77.1$ \\
\hline Copper & $54.17 \pm 0.76^{\mathrm{b}}$ & $39.92 \pm 0.68^{\mathrm{a}}$ & $38.88 \pm 0.77^{\mathrm{a}}$ & $<0.001$ & 0.0 & 0.2 & $13.80 \pm 3.68$ \\
\hline Zinc & $188.91 \pm 1.85^{c}$ & $41.65 \pm 0.65^{a}$ & $48.88 \pm 1.11^{\mathrm{b}}$ & $<0.001$ & -264 & 450 & $16.66 \pm 0.67$ \\
\hline Arsenic & $1.63 \pm 0.38$ & $1.88 \pm 0.11$ & $2.22 \pm 0.44$ & 0.187 & 0.6 & 3.2 & $9.73 \pm 0.81$ \\
\hline Lead & $1.09 \pm 0.07^{\mathrm{a}}$ & $2.55 \pm 0.05^{\mathrm{b}}$ & $3.49 \pm 0.07^{c}$ & $<0.001$ & -2.8 & 7.6 & $2.39 \pm 0.87$ \\
\hline Cadmium & $1.25 \pm 0.02^{\mathrm{b}}$ & $0.48 \pm 0.02^{\mathrm{a}}$ & $0.54 \pm 0.05^{a}$ & $<0.001$ & -1.1 & 2.6 & $1.32 \pm 0.02$ \\
\hline Chromium & $0.52 \pm 0.17^{a}$ & $1.45 \pm 0.22^{\mathrm{b}}$ & $1.53 \pm 0.11^{\mathrm{b}}$ & 0.001 & -1.2 & 3.6 & $0.80 \pm 0.55$ \\
\hline Nickel & $2.37 \pm 0.26^{\mathrm{a}}$ & $3.60 \pm 0.10^{b}$ & $3.65 \pm 0.60^{\mathrm{b}}$ & 0.01 & 0.1 & 6.3 & $5.72 \pm 0.11$ \\
\hline
\end{tabular}

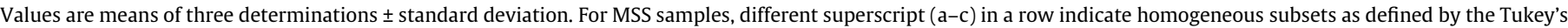
test $(\alpha=0.05)$. $P$ value, anova significance.

A $95 \%$ confidence interval defined for the three biological replicates of MSS.

B MSS, cultivated $U$. clathrata collected from a medium scale system.

C LSS, cultivated U. clathrata collected from a large scale system.

E. intestinalis, E. linza and U. lactuca from El-Mex Bay, Egypt. In the MSS1 sample, significantly higher contents were found for $\mathrm{Cu}$ (54 $\mathrm{mg} \mathrm{kg}^{-1} \mathrm{dw}$ ) and $\mathrm{Zn}\left(189 \mathrm{mg} \mathrm{kg}^{-1} \mathrm{dw}\right.$ ), compared to the other two MSS samples (13.8-39.9 and 16.7-48.9 $\mathrm{mg} \mathrm{kg}^{-1} \mathrm{dw}$ respectively). Similar high values have been reported by Orduña-Rojas and Longoria-Espinoza (2006) for U. lactuca collected in Navachiste Bay, Mexico. Except for MSS1 sample, $\mathrm{Cu}$ and $\mathrm{Zn}$ concentrations in cultivated $U$. clathrata agree with those reported for other Ulvales (Kumar et al., 2010; Mohamed \& Khaled, 2005; Paez-Osuna et al., 2000). In the present study, As was found in lower concentrations in MSS samples (1.6-2.2 $\mathrm{mg} \mathrm{kg}^{-1} \mathrm{dw}$ ) than in the LSS sample (9.7 $\left.\mathrm{mg} \mathrm{kg}^{-1} \mathrm{dw}\right)$. Previous As values reported for other ulvales fluctuated on the same levels (1.1-16 mg kg $\mathrm{gw}^{-1} \mathrm{dw}$ ) and were reported to be non-toxic for human health (Pérez et al., 2010; Rodríguez-Castañeda et al., 2006). Lead concentration ranged between 1 and $3.5 \mathrm{mg} \mathrm{kg}^{-1} \mathrm{dw}$; these values were lower than those reported in other ulvales studies (Mohamed \& Khaled, 2005; Orduña-Rojas \& Longoria-Espinoza, 2006). All samples presented low concentrations of $\mathrm{Cd}\left(0.48-1.25 \mathrm{mg} \mathrm{kg}^{-1} \mathrm{dw}\right)$ and $\mathrm{Cr}\left(0.52-1.53 \mathrm{mg} \mathrm{kg}^{-1}\right.$ $\mathrm{dw})$; Cd values were similar to those reported by Orduña-Rojas and Longoria-Espinoza (2006) and Paez-Osuna et al. (2000), while $\mathrm{Cr}$ values were lower compared to those reported in other ulvales (Paez-Osuna et al., 2000; Rodríguez-Castañeda et al., 2006). Ni concentrations among samples varied from 2.37 to $5.72 \mathrm{mg} \mathrm{kg}^{-1} \mathrm{dw}$, being higher in the LSS samples but consistent with values reported by Kumar et al. (2010) and Paez-Osuna et al. (2000). Because seaweeds concentrate metals to levels several times those found in the surrounding waters and integrate short-term temporal fluctuations, the levels of trace elements detected in water, fertilizers and soil in culture ponds must be controlled before culture production to assure that seaweed produced will be suitable for human consumption. There is little legislation on seaweeds in the European Union, so little control is exercised on potentially harmful metals. France was the first European country to set up regulations on the use of seaweeds for human consumption as non-traditional foods (Besada et al., 2009). Currently 12 macroalgae and 2 microalgae are authorised as vegetables and dressings/flavourings (Burtin, 2003). French limits for edible seaweeds are: $\mathrm{Pb}<$ $5 \mathrm{mg} \mathrm{kg}{ }^{-1}$ dw; $\mathrm{Cd}<0.5 \mathrm{mg} \mathrm{kg}^{-1}$ d.w; $\mathrm{Hg}<0.1 \mathrm{mg} \mathrm{kg}^{-1}$ d.w; and inorganic As $<3 \mathrm{mg} \mathrm{kg}^{-1} \mathrm{~d} . \mathrm{w}$. The content of As and Cd in the LSS Ulva analysed samples exceed these French limits. Cultivated $U$. clathrata could be a potential source of Fe; in humans, iron deficiency occurs mostly when the demand for iron is high, e.g., in growth, high menstrual loss, and pregnancy, and this can lead to anemia.

\section{Conclusion}

Variation between different laboratory (MSS) production batches was significant in regard to the analytical error for most determinations, except for fibre, some sugars (arabinose and uronic acids), some amino acids (taurine, hydroxyproline, serine, hydroxylysine and tryptophane), xanthophill pigments and As. Variations between MSS batches, in turn, did not allow separating the LSS sample for most determinations except for its higher content of soluble dietary fibre, $\mathrm{Ca}, \mathrm{Fe}, \mathrm{As}, \mathrm{Ni}$, threonine, hydroxyproline, serine, alanine, hydroxylysine and SFA, and for its lower content of $n-3$ PUFAs (especially linolenic acid), galactose, and ash. This research has shown that scale of culture systems and the growing conditions can be manipulated to modify the nutritional characteristics of this green seaweed for different nutritional purposes. The chemical composition of the cultivated $U$. clathrata analysed in this study, indicate that cultivated $U$. clathrata is a good source of SDF, high-quality PUFAs, carotenoids and some minerals; in larger quantities it can be a valuable source of protein and may be efficiently used as an ingredient in human and animal foods. Many of the virtues of Ulva overlap with those of fruits and vegetables that are more familiar in the Western diet, but Ulva is a much richer source of key functional components like soluble fiber. Many people eat diets that are based mainly on grains such as rice, wheat or maize. Such diets are typically deficient in iron; Ulva is an excellent source to supplement this mineral at low inclusion levels.

\section{Acknowledgements}

We thank Armando Leon (President and CEO of Aonori Aquafarms Inc. and Algalimentos SA de CV) and Dr. Benjamin Moll (Technical director of Aonori Aquafarms Inc. and Algalimentos SA de CV) for supplying samples of cultivated Ulva clathrata, as well as technical information on the algae growing systems, and manuscript editing advice. Special thanks to anonymous reviewers whose remarks helped to improve this paper.

\section{References}

Aguilera-Morales, M., Casas-Valdez, M., Carrillo-Domínguez, B., González-Acosta, B., \& Perez-Gil, F. (2005). Chemical composition and microbiological assays of marine algae Enteromorpha spp. as a potential food source. Journal of Food Composition and Analysis, 18(1), 79-88.

AOAC (2006). Official methods of analysis (18th ed.). Association of Official Analytical Chemists, Washington, DC, USA.

Besada, V., Andrade, J. M., Schultze, F., \& González, J. J. (2009). Heavy metals in edible seaweeds commercialized for human consumption. Journal of Marine Systems, 75(1-2), 305-313.

Bitter, T., \& Muir, H. M. (1962). A modified uronic acid carbazole reaction. Analytical Biochemistry, 4(4), 330-334.

Burtin, P. (2003). Nutritional value of seaweeds. Electronic Journal of Environmental Agricultural Food Chemistry, 2(4), 498-503.

Carrillo, S., López, E., Casas, M., Avila, E., Castillo, R., Carranco, M., et al. (2008). Potential use of seaweeds in the laying hen ration to improve the quality of $n-3$ fatty acid enriched eggs. Journal of Applied Phycology, 20(5), 721-728.

Chapman, V. J., \& Chapman, O. J. (1980). Seaweeds and their uses (3rd ed.). London: Chapman and Hall, p. 334 
Cruz-Suárez, L. E., León, A., Peña-Rodríguez, A., Rodríguez-Peña, G., Moll, B., \& Ricque-Marie, D. (2010). Shrimp/Ulva co-culture: a sustainable alternative to diminish the need for artificial feed and improve shrimp quality. Aquaculture, 301(1-4), 64-68.

Cruz-Suárez, L. E., Tapia-Salazar, M., Nieto-Lopez, M. G., Guajardo-Barbosa, C., \& Ricque-Marie, D. (2009). Comparison of Ulva clathrata and the kelps Macrocystis pyrifera and Ascophyllum nodosum as ingredients in shrimp feeds. Aquaculture Nutrition, 15(4), 421-430.

Dodson, J. R., \& Aroson, J. M. (1978). Cell wall composition of Enteromorpha intentinalis. Botanica Marina, XXI, 241-246.

Fleurence, J. (1999). Seaweed proteins: Biochemical nutritional aspects and potential uses. Trends in Food Science \& Technology, 10, 25-28.

Gómez-Pinchetti, J. L., Del Campo Fernández, E., Moreno-Díez, P., \& García-Reina, G. (1998). Nitrogen availability influences the biochemical composition and photosynthesis of tank-cultivated Ulva rigida (Chlorophyta). Journal of Applied Phycology, 10, 383-389.

Hayden, H. S., Blomster, J. A., Maggs, C. A., Silva, P. C., Stanthorpe, M. J., \& Waland, J. R. (2003). Linnaeus was right all along: Ulva and Enteromorpha are not distinct genera. European Journal of Phycology, 38, 277-294.

Hernández-Garibay, E., Zertuche-González, J. A., \& Pacheco-Ruiz, I. (2011). Isolation and chemicals characterization of algal polysaccharides from the green seaweed Ulva clathrata (Roth) C. Agardh. Journal of Applied Phycology. doi: 10.1007/s10811-010-9629-0.

Kosakai, M., \& Yosizawa, Z. (1979). A partial modification of the carbazole method of Bitter and Muir for quantitation of hexuronic acids. Analytical Biochemistry, 93, 295-298.

Kumar, M., Kumari, P., Trivedi, N., Shukla, M. K., Gupta, V., Reddy C. R. K., \& Jha, B. (2010). Minerals, PUFAs and antioxidant properties of some tropical seaweeds from Saurashtra coast of India. Journal of Applied Phycology. doi: 10.1007/ s10811-010-9578-7.

Kumari, P., Kumar, M., Gupta, V., Reddy, C. R. K., \& Jha, B. (2010). Tropical marine macroalgae as potential sources of nutritionally important PUFAs. Food Chemistry, 120(3), 749-757.

Lahaye, M. (1991). Marine algae as sources of fibers: Determination of soluble and insoluble dietary fiber contents in some 'sea vegetables'. Journal of the Science of Food and Agriculture, 54, 587-594.

Lahaye, M. (2001). Chemistry and physico-chemistry of phycocolloids. Cahiers de Biologie Marine, 42, 137-157.

Lahaye, M., Gómez-Pinchetti, J. L., Jimenez del Rio, M., \& Garcia-Reina, G. (1995). Natural decoloration, composition and increase in dietary fibre content of an edible marine algae, Ulva rigida (Chlorophyta), grown under different nitrogen conditions. Journal of the Science of Food and Agriculture, 68, 99-104.

Lahaye, M., \& Jegou, D. (1993). Chemical and physical-chemical characteristics of dietary fibres from Ulva lactuca (L.) Thuret and Enteromorpha compressa (L.) Grev. Journal of Applied Phycology, 5(2), 195-200.

Lahaye, M., \& Robic, A. (2007). Structure and functional properties of ulvan, a polysaccharide from green seaweeds. Biomacromolecules, 8(6), 1765-1774.

Lewis, B. (2008). Promoting eye and skin health through intake of the natural carotenoid lutein. In F. De Meester \& R. R. Watson. (Eds.), Wild-type food in health promotion and disease prevention (pp. 331-342). Humana Press Inc.: Totowa, NJ, USA.

Mabeau, S., \& Fleurence, J. (1993). Seaweed in food products: Biochemical and nutritional aspects. Trends in Food Science \& Technology, 4(4), 103-107.

Marinho-Soriano, E., Fonseca, P. C., Carneiro, M. A., \& Moreira, W. S. (2006). Seasonal variation in the chemical composition of two tropical seaweeds. Bioresource Technology, 18, 2402-2406.
Marsham, S., Scott, G. W., \& Tobin, M. L. (2007). Comparison of nutritive chemistry of a range of temperate seaweeds. Food Chemistry, 100(4), 1331-1336.

McDermid, K. J., \& Stuercke, B. (2003). Nutritional composition of edible Hawaiian seaweeds. Journal of Applied Phycology, 15(6), 513-524.

McHugh, D. J. (2003). A guide to the seaweed industry. Fisheries Technical Paper. No. 441. FAO, Rome.

Mohamed, L. A., \& Khaled, A. (2005). Comparative study of heavy metal distribution in some coastal seaweeds of Alexandria, Egypt. Chemistry and Ecology, 21(3), 181-189.

Moll, B. (2004). Aquatic surface barriers and methods for culturing seaweed. World Intelectual Property Organization, vol. WO 2004/093525.

Msuya, F. E., \& Neori, A. (2008). Effect of water aeration and nutrient load level on biomass yield, $\mathrm{N}$ uptake and protein content of seaweed Ulva lactuca cultured in seawater tanks. Journal of Applied Phycology, 20, 1021-1031.

Naidu, K. A., Tewari, A., Joshi, H. V., Viswanath, S., Ramesh, H. P., \& Rao, S. V. (1993). Evaluation of nutritional quality and food safety of seaweeds of India. Journal of Food Safety, 13(2), 77-90.

Orduña-Rojas, J., \& Longoria-Espinoza, R. M. (2006). Metal content in Ulva lactuca (Linnaeus) from Navachiste Bay (Southeast Gulf of California) Sinaloa, Mexico. Bulletin of Environmental Contamination Toxicology, 77, 574-580.

Ortiz, J., Romero, N., Robert, P., Araya, J., López-Hernandez, J., Bozzo, C., et al. (2006). Dietary fiber, amino acid, fatty acid and tocopherol contents of the edible seaweeds Ulva lactuca and Durvillaea antarctica. Food Chemistry, 99(1), 98-104.

Oxley, D., Currie, G., \& Bacic, A. (2004). In R. J. Simpson (Ed.), Analysis of carbohydrate from glycoproteins in purifying proteins for proteomics: A laboratory manual. Cold Spring Harbor, NY, USA: Cold Spring Harbor Laboratory Press (Chapter 25).

Paez-Osuna, F., Ochoa-Izaguirre, M. J., Bojorquez-Leyva, H., \& Michel-Reynoso, I. L. (2000). Macroalgae as biomonitors of heavy metal availability in coastal lagoons from the subtropical Pacific of Mexico. Bulletin of Environmental Contamination Toxicology, 64, 846-851.

Pérez, A. A., Pérez, L. B., Strobl, A. M., Camarda, S., Farías, S. S., López, C. M., et al (2010). Variación estacional de arsénico total en algas comestibles recolectadas en el Golfo San Jorge (Chubut, Argentina). Revista Latinoamericana de Biotecnología Ambiental y Algal, 1(1), 16-30.

Ray, B. (2006). Polysaccharides from Enteromorpha compressa: isolation, purification and structural features. Carbohydrate Polymers, 66(3), 408-416.

Rodríguez-Castañeda, A. P., Sánchez-Rodríguez, I., Shumilin, E. N., \& Sapozzhnikov, D. (2006). Element concentrations in some species of seaweeds from La Paz bay and La Paz lagoon, south-western Baja California, México. Journal of Applied Phycology, 18, 399-408.

Taboada, C., Millán, R., \& Míguez, I. (2009). Composition, nutritional aspects and effect on serum parameters of marine algae Ulva rigida. Journal of the Science of Food and Agriculture, 90, 445-449.

Valente, L. M. P., Gouveia, A., Rema, P., Matos, J., Gomes, E. F., \& Pinto, I. S. (2006) Evaluation of three seaweeds Gracilaria bursa-pastoris, Ulva rigida and Gracilaria cornea as dietary ingredients in European sea bass (Dicentrarchus labrax) juveniles. Aquaculture, 252(1), 85-91.

Ventura, M. R., \& Castañón, J. I. R. (1998). The nutritive value of seaweed (Ulva lactuca) for goats. Small Ruminant Research, 29(3), 325-327.

Wong, K. H., \& Cheung, P. C. K. (2000). Nutritional evaluation of some subtropical red and green seaweeds: Part I - proximate composition, amino acid profiles and some physico-chemical properties. Food Chemistry, 71(4), 475-482.

Yahia, E. M., Ramírez-Padilla, G. K., \& Carrillo-López, A. (2009). Carotenoid content of five fruits and vegetables and their bioconversion to vitamin a measured by retinol accumulation in rat livers. Acta Hort. (ISHS) 841, 619-624, http:// www.actahort.org/books/841/841_97.htm. 